\title{
The May 2015 boat crisis: the Rohingya in Aceh
}

\author{
Graham Thom \\ Amnesty International Australia ${ }^{1}$
}

\begin{abstract}
The 2015 discovery of mass graves in Thailand's Sadao district, on the border with Malaysia, led to a crackdown on people smugglers by the Thai and Malaysian authorities. Thousands of Rohingya (as well as Bangladeshi migrants) were left stranded in the Andaman Sea as smugglers abandoned their human cargo. Initially pushed back by the Thai, Malaysian and Indonesian navies, it was only after Indonesian fishermen rescued three boats that approximately 1,800 people were permitted to disembark in Indonesia's Aceh province. The crisis in the Andaman Sea brought into sharp relief the fact that the South East Asia region lacks even the most basic regional protection (or cooperation) framework. While some states are still reticent, there have been attempts to improve government collaboration as demonstrated recently in the March 2016 Bali Declaration on People Smuggling, Trafficking in Persons, and Related Transnational Crime. This paper examines, however, how the ad hoc approach by Indonesia's regions, in particular Aceh, to the treatment of the Rohingya who arrived in Aceh in May 2015, works against a comprehensive, national, rights-based approach to protect those seeking asylum in Indonesia. The paper explores the reasons why Aceh chose not to engage with the established practices for the treatment of asylum seekers in Indonesia and the human rights impacts this has had on those rescued. It concludes that the current situation in Aceh is not sustainable. The treatment of refugees in Aceh should be included in a broader national approach, commensurate with the treatment of refugees and asylum seekers throughout Indonesia, particularly if Indonesia is to develop a structured, rights-based approach to those seeking protection. This would then play a significant role in any future regional protection framework.
\end{abstract}

\section{Introduction}

Refugees and asylum seekers coming to Indonesia and seeking protection is not a new phenomenon. In recent years, however, this phenomenon has largely been associated with people smuggling operations and attempts to get people by boat to Australia. The refugee populations traveling to Indonesia in recent years have predominantly been from Afghanistan, Iraq, Sri Lanka and Iran. They have also included a small number of Rohingya arriving by

\footnotetext{
${ }^{1}$ The views expressed are those of the author and do not necessarily reflect those of Amnesty International Australia. Email: gthom@amnesty.org.au

ISSN: 1837-5391; https://epress.lib.uts.edu.au/journals/index.php/mcs CCS Journal is published under the auspices of UTSePress, Sydney, Australia

(C) 2016 Graham Thom. This is an Open Access article distributed under the terms of the Creative Commons Attribution 4.0 Unported (CC BY 4.0) License (https://creativecommons.org/licenses/by/4.0/), allowing third parties to copy and redistribute the material in any medium or format and to remix, transform, and build upon the material for any purpose, even commercially, provided the original work is properly cited and states its license.
} 
boat. The treatment of Rohingya who have arrived in Aceh previously, however, varies in significant ways from the treatment of those that arrived in May 2015.

Previous research has identified specific concerns with the treatment of refugees and asylum seekers in Indonesia more broadly, including examining the impact of Australia's regional deterrence policy in helping to shape Indonesia’s policy (Nethery \& Gordyn 2014; Nethery, Rafferty-Brown \& Taylor 2013; Taylor \& Rafferty-Brown 2010a). As noted by Taylor and Rafferty-Brown, 'Australia has posted immigration, customs, police and other officials in Indonesia to assist with the interception of people heading towards Australia and has poured billions of dollars in building Indonesia’s border control capacity' (2010a, p. 138). In general, these writers have concluded that the introduction of deterrence measures, for instance a greater use of detention, has significantly reduced the ability of asylum seekers to achieve effective protection, not just in Indonesia but in the Southeast Asia region more broadly (see also Nethery, Rafferty-Brown \& Taylor 2013, p. 105).

As this article will demonstrate, however, it is not only Indonesia's migration management, asylum seeker and refugee policies per se that are problematic, it is the ability for the regions within Indonesia to take an ad hoc approach to these policies that works against a protection based approach for refugees and asylum seekers in Indonesia and Southeast Asia more broadly. Nethery, Rafferty-Brown and Taylor also identified discrepancies among Indonesia's regions, both with regards to the regional experiences of asylum seekers and refugees in detention (2013, p. 98) and the conditions of residence depending on where they resided (2013 p. 93). However, the impact of an ad hoc approach (not just by states but within states) has been most clearly articulated by Cheung (2011) in his examination of the comparative experiences of Rohingya who fled in the early 1990s to Bangladesh and Malaysia. As Cheung notes:

\footnotetext{
'Case-by-case exceptions to the rule may arise but national treatment of refugees and asylum seekers continues to be ad hoc, depending on the nationality of the asylum seeker, regional strategic and political considerations and otherwise based on a remote sense of international obligations or humanitarianism left to the discretion of field-level immigration officials or magistrate judges' (2011, p. 63).
}

Aceh's most recent response to the Rohingya demonstrates that this is still occurring and not only at the discretion of local officials within the region. Significantly it was those governing the region itself, acting in many respects contrary to the established national practice, that 
undermined the rights of the rescued Rohingya despite beginning from a humanitarian approach.

This article is set out in six sections. The first section sets out the research methodology. The second section outlines the background to the 2015 crisis and how the Rohingya came to be rescued and taken to Aceh, despite the position of the national authorities at the time that they should not be brought to Indonesia. This section will also briefly compare the reception faced by the Rohingya with the established practice for asylum seekers arriving elsewhere in Indonesia. The third section will further demonstrate the discretionary, ad hoc, approach taken by officials in Aceh, by comparing the approach taken to the previous significant Rohingya boat arrivals in 2012. The fourth section will examine why Aceh changed its approach in 2015, from that experienced by previous arrivals, looking at some of the external and internal political drivers that help shape the recent ad hoc approach to the Rohingya in Aceh. The fifth section looks at the specific human rights impacts of these decisions on those seeking protection. This will compare both the initial positive local humanitarian support for the Rohingya, against the measures to confine them in (at least initially) ill-equipped sites and subject to strict local laws. The final section will examine the possible future direction of Indonesia's approach to those seeking protection particularly in light of the most recent Bali Declaration, in March 2016. It will conclude that for Indonesia to play a greater role in any Regional Protection Framework it will need to ensure a consistent approach to protection throughout Indonesia, limiting the scope for ad hoc decisions to be made in regions such as Aceh.

\section{Methodology}

The background research for this paper is primarily taken from field research I undertook as part of an Amnesty International research team, conducting research in Indonesia in August 2015. Our aim was to document the reasons driving the Rohingya to leave Myanmar and Bangladesh, the human rights abuses they experienced at sea, and the conditions they are experiencing in Aceh. While a detailed methodology is outlined in the Amnesty International report 'Deadly Journeys, The Refugee and Trafficking Crisis in Southeast Asia' (2015, p. 7), the research mission included 115 interviews with Rohingya refugees in Aceh (both group and individual), as well as Indonesian officials in Kuala Cankoi, Langsa and Lhokseumawe in Aceh province. In Jakarta we met with officials from Indonesia’s Directorate General for 
Immigration (Kantor Imigrasi), Ministry of Foreign Affairs, National Human Rights Commission and National Commission on Violence Against Women. Office of the United Nations High Commissioner for Refugees (UNHCR) and International Organisation for Migration (IOM) officials were interviewed in Aceh and Jakarta. Staff from over a dozen local civil society organisations in Aceh and Jakarta, including those working directly with the Rohingya in the sites, were also interviewed. We conducted a further 34 in-depth interviews with refugees (both Rohingya and other refugee nationalities) in Jakarta and Cisarua who had been in Indonesia for several months to several years. The Amnesty International report primarily documented the abuses suffered by those on board the smuggling/trafficking vessels. It also highlighted a number of issues now facing those allowed to remain in Aceh (Amnesty International, 2015). Following the release of the report, I undertook further research for this paper including interviews with both senior UNHCR and IOM officials in Jakarta, local and national NGOs in Indonesia, and international NGOs including the Arakan Project. I also had meetings with Australian officials to determine Australia’s engagement with Indonesia during the 2015 crisis and the likelihood Australia would provide assistance in case of any future crisis. National and regional media have provided further insights into the ongoing treatment of those rescued subsequent to our visit in August 2015.

\section{The rescue of the Rohingya in May 2015}

A considerable amount has already been published examining the background to the May 2015 boat crisis, including the Amnesty International report (2015, pp. 9-14). The ongoing human rights abuses facing the Rohingya have also been well documented (Equal Rights Trust 2014; Lowenstein 2015). While it is beyond the scope of this paper to give a detailed account of why people got on the boats and how they ended up stranded in the Andaman Sea, it is worth documenting, based on the research we undertook in August 2015, the timeline of their rescue and ultimately where they came ashore. This determined where they were to be held and the subsequent treatment they experienced.

The first boat to reach Indonesia was on 10 May, running aground in north Aceh. The 578 people on board either swam ashore or were assisted by locals and were ultimately taken to shelters in Lhokseumawe. After initially being housed in nearby Meunasah (a small mosque used by a village or neighbourhood), near to where they came ashore, they were then 
transferred to a converted warehouse closer to Lhokseumawe. On 12 August, they were moved to a purpose built site next door at Blang Adoe. The site was opened by the Deputy Governor of Aceh Muzakir Manaf (Portalsatu 2015).

On 15 May, 820 passengers were rescued by fisherman off east Aceh (having previously been towed towards Malaysia by the Indonesian navy on 11 May). This vessel is often referred to as the 'fighting ship' after violence broke out between Bangladeshi nationals and the Rohingya. A number of the Rohingya were reportedly killed in the violence and many of the Rohingya were forced to jump overboard and were rescued from the water by the Acehnese fishermen. Most of the 500 Bangladeshi nationals were quickly repatriated back to Bangladesh but over 200 Rohingya were taken to Langsa (Kota Langsa) (a further 43 were taken to Medan). While initially men and women were housed together in a converted warehouse in Langsa harbour, the 159 women and children were moved to Lhokbani (Kota Langsa) following concerns by Aceh officials about "sexual harassment" (although when interviewed, officials noted that it was more a concern with fraternising between the men and women as opposed to unwanted advances and actions from refugee men towards the women). The men were moved from the nearby warehouse to purpose built shelters next door.

On 20 May a final boat containing 409 passengers was rescued off east Aceh, again by fisherman. Over 300 of those rescued were taken to a makeshift site in Bayeun (Aceh Timur). Initial reports suggest this group were to be taken to Langsa and housed with the previous arrivals. However, the officials in Langsa stated they were already over stretched and did not allow them access. With little alternative, a makeshift camp was hastily erected in Bayeun. While the women and children were housed in a converted warehouse by the time of our visit in August 2015, the men remained sharing the large tents that initially housed them (although IOM has subsequently built more permanent structures for the men).

As of January 2016, in addition to the four sites in Aceh, the Rohingya were also accommodated in three locations in North Sumatra. While the first group taken to Medan is in the Beraspati Hotel in Medan, the people detained while trying to reach Malaysia are (as at April 2016) either in the Belawan detention centre in Medan or in the Immigration office in Tanjung Balai Asahan. 


\section{Situation facing refugees elsewhere in Indonesia}

While not a signatory to the 1951 Refugee Convention Relating to the Status of Refugees (the 1951 Refugee Convention), Indonesia’s response to refugee arrivals has developed to enable their access to UNHCR and publicly committing to respect non-refoulement obligations to those recognised in need of protection. While details of the refugee protection process in Indonesia can be found elsewhere (see Taylor \& Rafferty-Brown 2010b), it is worth noting that under Indonesian law it is still not possible to be granted refugee status. Rather, as noted by Sampson, Gifford and Taylor (2016, p. 5), in 2002 the Indonesian Immigration Directorate General issued a Directive protecting aliens from refoulement if they hold a UNHCR Attestation Letter or UNHCR identification card.

As at June 2015, there were 4,270 refugees in Indonesia and a further 6,916 individuals seeking asylum (UNHCR 2015c, p. 176). While the Indonesian Government has implemented a mandatory detention policy for people intercepted trying to enter or attempting to leave the country illegally, mechanisms are in place to have recognised refugees released into the community, including into community accommodation centres run, for instance, by IOM. Once in the community, there are no restrictions on the freedom of movement of refugees within Indonesia (see UNHCR 2015c, p. 176; Samson, Gifford \& Taylor 2016, p. 5).

For those seeking asylum, as well as recognised refugees in the community, serious issues remain. As noted by UNHCR: 'Formal legal and social rights and related benefits, including access to employment, are not accessible to refugees or asylum-seekers in Indonesia, and as such they are entirely dependent on support from UNHCR and its partners or from relatives abroad' (2015c, p. 176). UNHCR and NGOs in Indonesia have highlighted the worrying trend of refugees and asylum-seekers reporting themselves to immigration authorities preferring to be placed in detention where at least they are provided with food and shelter (UNHCR 2015c, p. 176). However, others have noted that despite 'a deep sense of insecurity and transience, this does not preclude [asylum seekers and refugees] from making a life in the face of such forces' (Sampson, Gifford \& Taylor 2016, p. 15). Many of those interviewed by Sampson, Gifford and Taylor (2016) were able to build meaningful lives despite the serious suffering and challenges they faced. 
Even with the lack of national legislation and the at times ad hoc approach by the Indonesian government to refugees and asylum seekers, the situation facing (and response to) the Rohingya who arrived in May 2015 varied considerably from the procedures in place throughout the rest of Indonesia. This has created a strange dichotomy whereby the Rohingya were welcomed by the Acehnese authorities and local population, while at the same time confined to "sites" with restrictions on their rights, including freedom of movement, that are not imposed on refugees in other parts of Indonesia.

Before examining the human rights impact of the recent approach undertaken by the authorities in Aceh it is worth examining the previous response by the Acehnese authorities to the arrival of Rohingya by boat. This is both to highlight the capacity for regions to take a varied and ad hoc approach to asylum seekers as well as to demonstrate, despite some similarities, the extent to which the latest approach in Aceh is unique, not just in Indonesia more broadly but in its own historical approach to the Rohingya.

\section{Previous response to the Rohingya boat arrivals}

While Rohingya have continued to arrive in small numbers to Indonesia over a number of years (most often via Malaysia), there were significant boat arrivals, including rescues by Acehnese fishermen, in 2012-13. This followed the surge in communal violence in Myanmar in June 2012 that saw an estimated 87,000 people depart the Bangladesh-Myanmar border area by boat between June 2012 and June 2014 (UNHCR 2014, p. 1). While the intended destination of those fleeing was primarily Malaysia, a number reached Indonesia, including (similar to 2015) at least one boat that had been pushed back out to sea by the Thai navy. In the first 6 months of 2013, UNHCR registered 565 Rohingya in Indonesia (UNHCR 2014, p. 5).

At least publicly, similar to the arrivals in May 2015, Indonesia and Aceh’s responses to the Rohingya differed from those to other refugee arrivals, with expressions of solidarity with their plight. The reasons for the different public responses, as reported in April 2013 (Bachelard 2013), were reiterated by both local and international NGOs we met with. These included that the Rohingya were fellow Sunni Muslims who were fleeing religious persecution from within the region. There was further empathy in Aceh where many of the officials were able to relate on a personal level, having had to flee to Malaysia during the 
conflict in Aceh. However, while expressing solidarity with the Rohingya people, the Indonesian government (similar to 2015) attempted to seek alternative countries to settle them although these diplomatic efforts focused predominantly on the Middle East (Bachelard 2013).

In many respects the initial humanitarian response in 2013 was similar to that experienced by the arrivals in May 2015. The local community and civil society donated food, clothing and sanitary items. IOM provided food and relief supplies and UNHCR interviewed them to assess their protection needs (UNHCR 2013). However, unlike in 2015, the vast majority did not remain in Aceh and were instead taken to Medan and at least initially detained in the Belawan IDC. There were issues with overcrowding in the Belawan IDC and there was the tragic event in April 2013 when, following allegations of sexual harassment, 18 Rohingya allegedly beat and stabbed to death eight Buddhist fishermen, also from Myanmar (Bachelard 2013). Various news agencies reported 15 to 21 Rohingya were injured during the three hours of violence (see, for instance, Gunawan 2013).

Interviews with both UNHCR and IOM highlighted that after processing by UNHCR, the Rohingya were generally released into the community and were either housed in IOM shelters or they moved independently throughout Indonesia or again engaged smugglers and travelled to Malaysia. The fact that many travelled to Malaysia in part explains the response to those who arrived in 2015 who were confined to 'sites', although it is not the only explanation.

\section{Why did the treatment for the 2015 arrivals change?}

As the boat crisis in May 2015 unfolded, the foreign ministers of Malaysia, Indonesia, and Thailand met in Putrajaya, Malaysia, on 20 May. At this meeting, Malaysia and Indonesia agreed to offer 'temporary shelter provided that the resettlement and repatriation process will be done in one year by the international community' (Joint Statement 2015, p. 4). It should be noted, however, that the Acehnese fisherman had already rescued the three boats prior to this agreement. During our interviews in Aceh in August 2015 there appeared to be a genuine solidarity with the Rohingya people both from the local community, NGOs, local governments and the regional government (Amnesty International 2015, pp. 29 - 30). Previous practice, coupled with the lack of resources in Aceh and a lack of experience 
supporting asylum seekers generally, still raises questions as to why the authorities in Aceh in May 2015 decided that this group of Rohingya should remain there.

As noted above, Indonesia in 2011 implemented a mandatory detention policy for all those arriving or attempting to leave the country illegally. However this did not occur for the Rohingya arriving in Aceh in 2015. Instead, from our interviews with local officials and NGOs, the decision to keep them in Aceh appears to have come at first from the local government, that is, the municipality and regency, not the governor nor the national authorities. This decision was officially authorised when the central government, especially the President through the Minister of Foreign Affairs, decided to give them shelter for a one year period.

According to an interview with Febi Yonesta, Public Lawyer at the Jakarta Legal Aid Institute (LBH Jakarta):

The decision was taken by the local government after a meeting with the Minister of Social Welfare, UNHCR, IOM, the rapid response unit for disaster management, and local NGOs in Kota Langsa Aceh on 24 May 2015. The local government then issued a decree on a "task force" for dealing with Rohingya asylum seekers and migrants from Bangladesh. The Medan local government was refusing to receive more refugees, while the Aceh Mayor of Kota Langsa was more open to taking the Rohingya. Ultimately the decision was dependent on the head of the local government's discretionary powers and his tendency to favour the refugees, in this case Rohingya. The other factor was the guarantee from IOM to provide all logistical needs, which needed the central government approval for this purpose, as IOM is only partnering with the central government immigration directorate (Yonesta, January 2016).

It is clear from officials interviewed during our research in Aceh that the authorities felt a compelling and genuine humanitarian need to provide assistance to the Rohingya.

For instance, officials in Lhokseumawe donated land to house hundreds of arrivals in an integrated community shelter in Blang Adoe, which was built to house the Rohingya. Also, numerous civil society organisations across the region are working to meet the Rohingyas' basic needs, such as housing, food, water, medical care and education (Amnesty International 2015, p. 30). 
An argument could be made that as these individuals were rescued (rather than them having deliberately set out to enter Indonesia), they had not entered illegally. The announcement by the Foreign Minister on 20 May further suggested they had a right to be in the country and should not face mandatory detention (Joint Statement, 2015). This raises questions about why the Rohingya were confined to the 'sites'.

The high profile nature of the May 2015 crisis and the international response to it (with significant amounts of aid promised and largely contributed by Japan, Turkey, the European Union, the United States of America (USA) and Qatar) is likely to have played a role in the decisions by local authorities to favour the Rohingya staying there. With IOM agreeing to cover the logistical needs, significant international aid was provided not only to UNHCR and IOM but also, as indicated by NGOs we interviewed in Indonesia, to international and local NGOs operating in Aceh. As one of the poorest provinces in Indonesia, this provided a much needed boost to the local economy.

\section{Concerns with the treatment in Aceh}

By moving away from national systems in place elsewhere throughout Indonesia and establishing a new process, a number of issues arise which question the long term sustainability of this approach. These concerns (as outlined below), combined with the fact that the Rohingya were aiming to reach Malaysia and that this remains the preferred destination for most, makes the long term viability highly questionable.

It is apparent that the Rohingya are already voting with their feet. By the beginning of December 2015 it was reported that less than 400 of the 1000 Rohingya initially rescued remained in the camps. Virtually all those who have left are believed to have engaged smugglers and travelled to Malaysia (Vit 2015). According to UNHCR in subsequent interviews, by mid January 2016 only 316 individuals remained.

While human rights organisations continue to document serious concerns with the treatment of Rohingya in Malaysia, (see, for instance, Equal Rights Trust 2014), the fact remains this is the country of choice for Rohingya escaping Myanmar by boat. In Malaysia, the vast majority of refugees and asylum seekers registered with UNHCR are from Myanmar. At the end of September 2015, out of 153,850 refugees and asylum seekers, 142,630 were from Myanmar, 
with 50,030 of these registered as Rohingya (UNHCR 2015a). There is also a significant number of Rohingya yet to be registered (Equal Rights Trust 2014, p. 15). The large Rohingya diaspora, the ability to live in the community (despite still being considered 'illegal migrants') and practice their religion and work (albeit 'illegally') in the informal sector, are all factors that continue to draw Rohingya fleeing persecution in Myanmar to Malaysia.

Most of the Rohingya we spoke to in Aceh risked the dangerous journey to get to Malaysia either to reunite with family or, for the young girls and women, to meet husbands. The young men were hoping to find work to support their family or gain access to education denied to them in Myanmar and Bangladesh. It was clear smugglers were quick to make contact with those in the 'sites' in Aceh, with the promise of ensuring they could reach Malaysia, provided they could afford an additional fee (Malay mail online, August 2015). This promise, coupled with the uncertainty and conditions in the sites in Aceh, clearly provided an incentive to most to leave already. Based on our interviews and having witnessed the conditions in the sites firsthand, there are a number of other concerns relating to the current response to the Rohingya in Aceh which have contributed to the decision for many of the Rohingya to leave.

\section{Task force coordination}

Who is ultimately in charge is not immediately evident when you visit each of the 'sites' in Aceh. The official answer is that there is a taskforce in place to administer the centres. As noted above, these taskforces were implemented following an agreement with the national authorities and local authorities on 24 May. The local Mayor is nominally in charge of the taskforce with a national immigration official working on each. Other members of the taskforce include UNHCR and IOM. However, other interested parties were also invited to participate. The lack of clarity and coordination around who was supposed to be doing what was clearly apparent during our visit, with the unfortunate consequence of an overlap of certain services for some groups of Rohingya, particularly the children, while others received virtually no attention.

\section{Conditions}

During our research we were able to visit each of the 'sites' in Aceh and we subsequently documented concerns with the conditions in the camps (Amnesty International 2015). This included 'poor sanitation, insufficient protection from the elements, as well as unsanitary cooking facilities’ (Amnesty International 2015, p. 33). The conditions varied from camp to 
camp with those faced by the men in the Bayeun site (sleeping in inadequate tents) clearly the most problematic and in stark contrast to the purpose built accommodation at Blang Adoe. The basic accommodation at the Kuala Langsa site, surrounded by pools of water, was also substandard. It was clear that many (including those who constructed the purpose built accommodation) saw the 'sites' as only necessary for twelve months. However, what was less clear was what was going to happen after twelve months. In addition, while a new facility is under construction in Timbang Langsa, with a capacity of around 300 people, there appears to be little coordination with the major agencies operating there to ensure the site meets appropriate standards.

\section{Safety}

Linked to the conditions in the sites are also serious issues relating to the safety of the Rohingya confined there. Concerns were raised by the men at the Kuala Langsa site that, due to its isolation, local gangs had entered the site on a number of occasions to rob and beat them. At other sites the Rohingya had raised safety issues relating to the security guards, accused of abuse and intimidation. When searching for mobile phones, local male police officers were accused of inappropriate pat-downs, including using the pretext of searching for mobile phones to grope women's breasts. When interviewing local officials, it was evident that they saw the primary role of security officers to stop people smugglers operating in the sites, rather than the personal security of the Rohingya in the sites.

\section{Sharia Law}

Adding another layer to the personal safety of the Rohingya in the sites is that Aceh, alone among Indonesia's provinces, has been authorised under national law to implement local Sharia law. In its 2010 report, Human Rights Watch (HRW) identified a number of concerns with two laws in particular: the Seclusion law (prohibiting unmarried individuals of different sexes from being together in certain circumstances), and the Muslim Dress Laws (imposing public dress requirements on Muslims). The potential for severe punishments, including physical punishments for those found violating these laws, is highly problematic for the Rohingya confined in the sites (HRW 2010). It is clear that the Sharia police known as the Wilayatu Hisbah (WH) are operating in the sites and allegations were made to us that physical punishments for non-observance of these laws had already been meted out to the Rohingya, prior to our visit. 
The way Sharia law is being applied to the Rohingya creates a dilemma for UNHCR, as on the one hand refugees in any country are expected to abide by the laws of that country. However, on the other hand, the Rohingya were not attempting to reach Aceh. They are now being held in a confined space against their will and face severe punishments, including forced marriage, for conduct that is lawful elsewhere in Indonesia (and Malaysia).

\section{Economic conditions}

The economic situation in Aceh also creates concerns for the long term viability of housing the Rohingya there. Even if they were allowed to work, finding a job would be extremely difficult. A number noted to us that the difference in the amount they would be paid, assuming they could find a job, compared to what they could earn in Malaysia, would be significantly less.

It is very unclear what will happen after the twelve-month period set for a solution by the Indonesian government expires in May 2016. If the Rohingya have not been resettled (and it is highly unlikely they will be), will the local authorities or the national government have the funding to keep them in the sites? With record displacement around the world, how long will the international community continue to fund the specific treatment of this group of Rohingya (compared to Rohingya elsewhere in Indonesia), particularly as the numbers in Aceh dwindle? Without international funding, it is unlikely that the local governments will be able to maintain the current levels of support.

\section{Family Reunion}

Of the 950 Rohingya initially rescued, some 328 had been identified as unaccompanied minors or separated children. While a number of the teenagers we interviewed still had family either in Myanmar or Bangladesh, the vast majority were trying to reunite with a relative in Malaysia. This included teenage girls (including some as young as 14) trying to reach husbands in Malaysia that had been arranged for them by their parents in Myanmar or Bangladesh. A number of the women we spoke to with children were also trying to reach their husbands in Malaysia. As refugees they could not be returned to Myanmar and as Rohingya it is highly unlikely that the governments of Bangladesh or Malaysia would let them enter their countries, particularly to reunite with family that were not likely to have the legal status to be there. Once again, as far as the Rohingya could see, the only way to reunite with family is through people smuggling networks. 
The Jesuit Refugee Service in Indonesia documented the situation of one family being separated in different camps in Aceh after being rescued (Jesuit Refugee Service 2015). This situation was also mentioned to us in relation to another family during our visit in August 2015. Given that authorities were having difficulties in reuniting families within Indonesia, this is likely to be impossible to organise across a number of countries.

\section{Resettlement}

While it is clear there is an expectation from the Indonesian government that the Rohingya in Aceh will be resettled by May 2016, this is would appear to be highly unlikely, even with the dwindling numbers in Aceh. In reality very few countries resettle refugees out of Indonesia and even fewer resettle Rohingya (UNHCR 2015b, p. 5). Previously one of the biggest countries of resettlement from Indonesia was Australia, however, for the financial year 201415 Australia reduced the number of refugees it resettled from Indonesia to 450 people, and not one appears to have been from Myanmar (Parliament of Australia 2015). Australia has also announced it will not resettle anyone from Indonesia who arrives there after 1 July 2014 (Parliament of Australia 2015). As such Australia will not be able to play any constructive role in assisting UNHCR and Indonesia in resettling this group.

The USA has now taken over as the key resettlement country for refugees in Indonesia. For the first six months of 2015, 569 of the 590 cases submitted by the UNHCR in Indonesia for resettlement were accepted by USA. However, the vast majority are refugees from Afghanistan or Somalia (UNHCR 2015b, p. 5). Refugees from Myanmar now make up the second biggest caseload for UNHCR in Indonesia and while it has stated that 'Rohingya refugees from Myanmar will continue to be identified for resettlement based on particular vulnerability' (UNHCR 2015c, p. 177), in 2016 only 50 out of the 1,200 people the UNHCR proposes for resettlement from Indonesia are from Myanmar. Other than the small number of Rohingya the UNHCR has already submitted for resettlement from those who are particularly vulnerable in Aceh (including women and children at risk), it is difficult to envisage significant numbers being prioritised from Aceh given there have been other Rohingya elsewhere in Indonesia for a number of years. 


\section{Is the current arrangement in Aceh sustainable?}

The long term sustainability of this unique response to refugee arrivals in Aceh must be questioned. If the Indonesian authorities wish to create a sustainable system in Aceh then, in the first instance, they must address the uncertainty created by the announcement that a solution will need to be found by 20 May 2016. The uncertainty remains, not only at the national government level, but also at the local government level and among the refugees themselves. There is also little incentive for the local authorities or international donors to invest in improving the facilities if the national government could adopt a completely different approach after May 2016.

Even with the uncertainty, some attempts are being made to improve the conditions and the commitment from the local authorities towards the Rohingya appears genuine. However, a lack of coordination, expertise and experience in responding to the needs of refugees and asylum seekers continues to undermine a more comprehensive approach that would offer a durable solution to those in Aceh. At a minimum moving the most vulnerable, or those with special needs, to a more appropriate environment (including elsewhere in Indonesia) would be an important first step.

There are a number of key initiatives that need to be implemented if the ongoing response to the Rohingya in Aceh is to have any chance of success. First, it needs to be part of a national approach to refugees and asylum seekers that not only provides a clear and operational legal framework but also includes basic rights such as the freedom of movement as well as access to education and employment. As noted by Amnesty International, Indonesia has been developing a Presidential Regulation since 2011, which would appear positive with respect to the rights it will afford refugees (2015, p. 31). These need to be implemented as a matter of urgency, with a clear understanding that they also apply to the refugees in Aceh.

While this will hopefully lead to a number of refugees remaining in Indonesia for longer periods, the international community needs to do more to support Indonesia by offering meaningful resettlement quotas. Currently the USA is resettling the vast majority of refugees out of Indonesia and given that its approach to resettlement is based on vulnerability criteria, it is open to take both Rohingya and unaccompanied humanitarian minors. Other resettlement countries need similarly to increase both their overall quotas as well as expand the range of 
nationalities that can be submitted to them by UNHCR. Regional solutions are also needed so those with family in Malaysia can be reunited without having to rely on people smugglers.

Despite the fact that many Rohingya who arrived by boat in 2012-13 made their way through people smugglers to Malaysia, others remained in Indonesia even though there was a limited opportunity to be resettled and they were considered 'illegal migrants' under Indonesian law. While it would not stop all future boat arrivals from making their own way to Malaysia, a national system that included basic rights, with a greater commitment from the international community to support Indonesia through resettlement, would clearly have a greater chance of success than the ad hoc approach currently in place.

\section{Conclusion}

Following field research undertaken in Aceh in August 2015, this article has examined the human rights situation facing the Rohingya that arrived in Aceh in May 2015, why they have been treated differently from previous Rohingya groups who have arrived in Aceh, and the ongoing sustainability of the current model. Significantly, due to a number of the concerns raised above, the majority of those who arrived have subsequently escaped from the 'sites' where they were housed, having again engaged smugglers to reach Malaysia. The response by the officials in Aceh not only raises concerns about the treatment of the Rohingya in Indonesia, it also raises issues in relation to the ad hoc approach taken by regional authorities within Indonesia to those seeking protection, as well as by national governments in Southeast Asia more broadly.

The situation facing the Rohingya who arrived in Aceh in 2015 in many ways mirrors the response documented by Cheung (2011) about the Rohingya in Bangladesh and Malaysia in 2009 who had fled Myanmar in the 1990s. As well as noting the ad hoc responses to Rohingya seeking protection, shaped by domestic sentiment and fluctuating institutional practices rather than official state policies, Cheung also noted that these practices are generally characterised by often punitive immigration control measures and a general reluctance to offer long term durable solutions (2011, p. 51). Refugees, despite being somewhat secure from refoulement, are also short of receiving a regularised right to stay and hence 'have suffered from the lack of formal, consistent policies' (2011, p. 51) in the Southeast Asia region. The ad hoc approaches are shaped by a general migration-orientated 
approach that has been coupled with a reluctance to assume responsibility for finding durable solutions for those in need of protection.

When examining the way refugees and asylum seekers are discussed in regional and Ministerial processes in both the South and Southeast Asia region in 2009, Cheung noted the lack of a 'clear reference to or foundation in the rights-based framework of protection' (2011, p. 64). The region failed to respond using the human rights mechanisms in the ASEAN charter, instead preferring to use the Bali Process that was established to enhance border control, security and law enforcement mechanisms. However, what was significantly different about the May 2015 crisis to the events of 2009 was the complete failure of the Bali Process. A strong contribution to this failure was the reluctance of Australia (Co-Chair of the Bali Process), at least initially, to engage in any meaningful way with the crisis. The former Australian Prime Minister Tony Abbott responded: 'nope, nope, nope’ when asked if Australia would offer to resettle any of the thousands caught in the crisis, believing that any resettlement would further encourage the people smuggling trade (quoted in Cox 2015). Still, while key ASEAN nations eventually met to resolve the crisis, the statements from Indonesia and Malaysia following the meeting in Putrajaya, Malaysia on 20 May 2015 fell short of providing durable solutions for those rescued, again reiterating a third country resettlement solution would need to be found for those rescued.

While a change in Prime Minister in Australia in September 2015 did not see any offers of resettlement places for the rescued Rohingya, it did see Australia take a more proactive role in the Sixth Ministerial Conference of the Bali Process on 23 March 2016. While discussions of the May 2015 crisis featured heavily at the Conference, importantly the Co-Chairs’ (Australia and Indonesia) Statement and the subsequent Bali Declaration on People Smuggling, Trafficking in Persons, and Related Transnational Crime (the Declaration) not only highlighted the need for a review of the region's response to the May 2015 crisis, it also acknowledged the need for a comprehensive regional approach which included a number of important protections for refugees and asylum seekers in the region. The Declaration recognised 'the need to grant protection for those entitled to it, consistent with relevant international legal instruments and in all cases, the principle of non-refoulement should be strictly respected’ (Bali Declaration 2016, pp. 2-3). It also welcomed appropriate local solutions, encouraging members to explore local stay arrangements for refugees and asylum seekers and explore alternatives to detention for vulnerable groups. 
What this article has demonstrated, however, is that Indonesia will not be able to contribute to a comprehensive regional approach until it implements formal, consistent policies that are both rights-based and legally binding throughout Indonesia. As long as regions within Indonesia are able to apply ad hoc approaches to asylum seekers and refugees, effective protection will continue to be undermined and with it Indonesia's ability to take a leadership role on these issues in the Asia-Pacific.

\section{References}

Amnesty International, 2015, 'Deadly Journeys: The Refugee and Trafficking Crisis in Southeast Asia,’ October. Accessed: 22 October 2015 https://www.amnesty.org/en/documents/ASA21/2574/2015/en/

Asylum Insights, 'Facts and Analysis, Indonesia.' Accessed: 19 January 2016 http://www.asyluminsight.com/indonesia/\#.VpxbIJp94dU

Bachelard, M. 2013, 'Rohingya refugees a growing problem for Indonesia', The Sydney Morning Herald, April 9. Accessed: 15 January 2016 http://www.smh.com.au/world/rohingya-refugees-a-growing-problem-for-indonesia20130408-2hh6w.html

Bali Declaration on People Smuggling, Trafficking in Persons, and Related Transnational Crime, The Sixth Ministerial Conference of the Bali Process on People Smuggling, Trafficking in Persons and Related Transnational Crime, Bali, 23 March 2016. Accessed: 5 April 2016 http://www.baliprocess.net/files/Bali\%20Declaration\%20on\%20People\%20Smuggling \%20Trafficking\%20in\%20Persons\%20and\%20Related\%20Transnational\%20Crime\%2 02016.pdf

Cheung, S. 2011, 'Migration control and the solutions impasse in South and Southeast Asia: Implications from the Rohingya experience.' Journal of Refugee Studies, vol. 25, no. 1, doi: http://dx.doi.org/10.1093/jrs/fer048

Co-Chairs Statement, The Sixth Ministerial Conference of the Bali Process on People Smuggling, Trafficking in Persons and Related Transnational Crime, Bali, 22 March 2016. Accessed: 5 April 2016 http://www.baliprocess.net/files/SOM\%20cochairs\%20statement\%20-\%20FINAL_160322\%20\%2022\%20March\%202016\%20Bali.pdf

Cox, L. 2015, “"Nope, nope, nope”: Tony Abbott says Australia will not resettle refugees in migrant crisis’, Sydney Morning Herald, 21 May. Accessed 15 January 2016: http://www.smh.com.au/federal-politics/political-news/nope-nope-nope-tony-abbottsays-australia-will-not-resettle-refugees-in-migrant-crisis-20150521-gh6eew.html

Crock, M. 2014, 'Shadow plays, shifting sands and international refugee law: Convergences in the Asia-Pacific,' International and Comparative Law Quarterly, vol. 63, pp 247280, doi: http://dx.doi.org/10.1017/S0020589314000050

Equal Rights Trust, 2014, 'Equal only in Name: The human rights of stateless Rohingya in Malaysia’, London, October. Accessed 21 January 2016 http://www.equalrightstrust.org/ertdocumentbank//Equal\%20Only\%20in\%20Name\%20 -\%20Malaysia\%20-\%20Full\%20Report.pdf 
Fan, L. 2014, ‘Aceh’s unfinished recovery’, IRIN, Banda Aceh, 26 December. Accessed: http://www.irinnews.org/report/100972/aceh

Galache, C. S. 2015, 'In Indonesia’s Aceh, a warm welcome for refugees in a sea of misery', IRIN, Langsa, Indonesia, 15 June. Accessed 15 January 2016:

http://www.irinnews.org/report/101631/in-indonesia-s-aceh-a-warm-welcome-forrefugees-in-a-sea-of-misery

Gunawan, A. 2013, '8 Myanmar detainees die in Medan brawl', The Jakarta Post, 6 April. Accessed: 21 January 2016http://www.thejakartapost.com/news/2013/04/06/8myanmar-detainees-die-medan-brawl.html

Human Rights Watch, 2010, 'Policing morality abuses in the application of Sharia in Aceh, Indonesia’, December. Accessed 5 April 2016

https://www.hrw.org/report/2010/11/30/policing-morality/abuses-application-shariaaceh-indonesia

Jesuit Refugee Service, 2015, 'Syaitara longing for her mother’, 12 August. Accessed: 5 April 2016 http://jrs.or.id/en/campaigns/urban-refugees/rindu-syaitara-pada-ibunya/

Joint Statement, 2015, 'Ministerial Meeting on Irregular Movement of People in Southeast Asia’, Putrajaya, Malaysia, p4, Wednesday, 20 May. Accessed 21 January 2016 http://www.nytimes.com/interactive/2015/05/20/world/asia/document-malaysiaindonesia-thailand-statement-on-asia-migrants-crisis.html

Lowenstein, A. K. 2015, 'Persecution of the Rohingya Muslims: Is genocide occuring in Myanmar’s Rakhine State? A legal analysis', prepared for Fortify Rights, October. Accessed: 5 April 2016 http://www.fortifyrights.org/downloads/Yale_Persecution_of_the_Rohingya_October_ 2015.pdf

Malay mail online, 2015, 'Rohingya refugees “disappear” from Aceh detention centres, smuggled to Malaysia’, 6 November. Accessed 13 November 2015 http://www.themalaymailonline.com/malaysia/article/rohingya-refugees-disappearfrom-aceh-detention-centres-smuggled-into-malay

Missbach, A. 2016, 'The Rohingya in Aceh: displaced, exploited and nearly forgotten', Indonesia at Melbourne, The University of Melbourne, 14 March. Accessed 5 April 2016 http://indonesiaatmelbourne.unimelb.edu.au/the-rohingya-in-aceh-displacedexploited-and-nearly-forgotten/

Nethery, A. \& Gordyn, C. 2014, 'Australia-Indonesia cooperation on asylum-seekers: A case of "incentivised policy transfer”, Australian Journal of International Affairs, vol. 68, no. 2, pp. 177-193. doi: http://dx.doi.org/10.1080/10357718.2013.841122

Nethery, A., Rafferty-Brown, B. \& Taylor, S. 2013. 'Exporting detention: Australia-funded immigration detention in Indonesia', Journal of Refugee Studies, vol. 26, no. 1, pp. 88109. doi: http://dx.doi.org/10.1093/jrs/fes027

Parliament of Australia, 2015, Refugee Resettlement to Australia: what are the facts? Update 3 February 2015. Accessed: 21 January 2016 http://www.aph.gov.au/About_Parliament/Parliamentary_Departments/Parliamentary Library/pubs/rp/rp1415/RefugeeResettlement

Portalsatu, 2015, News Website, 12 August. Accessed 21 January 2016 http://archives.portalsatu.com/news/foto-wagub-aceh-resmikan-shelter-rohingya-blangadoe/

Pudjiastuti, T. N. (translated and edited by Missbach, A. Tan, N. F.) 2016, 'Shelter versus shielded borders, Inside Indonesia, Edition 124: Apr-Jun 2016. Accessed 21 January 2016 http://www.insideindonesia.org/shelter-versus-shielded-borders 
Sampson, R. C., Gifford, S. M. \& Taylor, S. 2016: 'The myth of transit: the making of a life by asylum seekers and refugees in Indonesia', Journal of Ethnic and Migration Studies, doi: http://dx.doi.org/10.1080/1369183X.2015.1130611

Taylor, S. \& Rafferty-Brown, B. 2010(a), 'Difficult journeys: Accessing refugee protection in Indonesia', Monash University Law Review, vol. 36, no. 3, pp. 138-161.

Taylor, S. \& Rafferty-Brown, B. 2010(b), 'Waiting for life to begin: The plight of asylum seekers caught by Australia’s Indonesian solution', International Journal of Refugee Law, vol. 22, no.4, pp. 558-592. doi: http://dx.doi.org/10.1093/ijrl/eeq034

UNHCR 2013, 'UNHCR concern at reports of shooting involving Rohingya boat people', Briefing Notes, 15 March. Accessed 21 January 2016 http://www.unhcr.org/5143076c9.html

UNHCR 2014, 'South-East Asia Irregular Maritime Movements January-June 2014’. Accessed 21 January 2016 http://www.refworld.org/country,COI, ,IDN,,53f74c194,0.html

UNHCR 2015a, 'Figures at a glance', Malaysia. Accessed 25 January 2016 http://www.unhcr.org.my/About_Us-@-Figures_At_A_Glance.aspx

UNHCR 2015b, Indonesia Monthly Statistical Report, July, Jakarta.

UNHCR 2015c, Projected Global Resettlement Needs 2016, Restricted Distribution, $21^{\text {st }}$ Annual Tripartite Consultation on Resettlement, Geneva, 29 June-1 July.

University of New South Wales, Andrew \& Renata Kaldor Centre for International Refugee Law, 2013, 'Regional Cooperation’ 29 October. Accessed: 5 April 2015.

http://www.kaldorcentre.unsw.edu.au/publication/regional-cooperation

Vit, J. 2015, 'Rohingya refugees vanish from Indonesia,' IRIN, 14 December, Jakarta. Accessed 25 January 2016 http://www.irinnews.org/report/102293/rohingya-refugeesvanish-from-indonesia

Yonesta, F. January 2016, (interview), Public Lawyer, The Jakarta Legal Aid Institute (LBH Jakarta). 